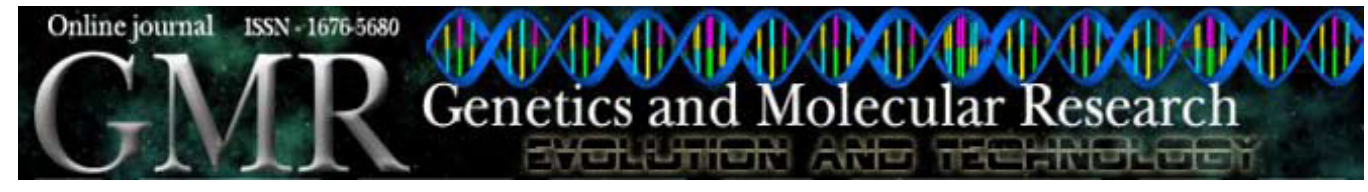

\title{
Male sleeping aggregations of solitary oil-collecting bees in Brazil (Centridini, Tapinotaspidini, and Tetrapediini; Hymenoptera: Apidae)
}

\author{
I. Alves-dos-Santos ${ }^{1}$, M.C. Gaglianone ${ }^{2}$, S.R.C. Naxara ${ }^{1}$ and M.S. Engel ${ }^{3}$ \\ ${ }^{1}$ Departamento de Ecologia, Instituto de Biociências, \\ Universidade de São Paulo, São Paulo, SP, Brasil \\ ${ }^{2}$ Laboratório de Ciências Ambientais, \\ Centro de Biociências e Biotecnologia, \\ Universidade Estadual do Norte Fluminense, \\ Campos dos Goytacazes, RJ, Brasil \\ ${ }^{3}$ Division of Entomology (Paleoentomology), \\ Natural History Museum, and Department of Ecology and Evolutionary Biology, \\ University of Kansas, Lawrence, KS, USA \\ Corresponding author: I. Alves-dos-Santos \\ E-mail: isabelha@usp.br \\ Genet. Mol. Res. 8 (2): 515-524 (2009) \\ Received December 12, 2008 \\ Accepted January 26, 2009 \\ Published May 12, 2009
}

\begin{abstract}
Males of solitary bees usually spend the night in clusters on small branches of plants, cavities and flowers. The individuals usually return to the same location each evening during their life, exhibiting site fidelity to a particular plant. We report on the sleeping roosts of the males of some oil-collecting bees of the genera Centris, Paratetrapedia, Lanthanomelissa, Monoeca, and Tetrapedia, as well as the host plants. We discuss the role of the male clusters to the associated plants.
\end{abstract}

Key words: Neotropical bees; Centris; Lanthanomelissa; Monoeca; Paratetrapedia; Tetrapedia 


\section{INTRODUCTION}

In the life cycle of a solitary bee, the female performs all the tasks of nest construction, maintenance, and provisioning alone. There is often no contact between the generations, usually with the mother departing or dying many months before the new generation emerges. Typically, males emerge a few days before females and start to search for freshly emerged virgins to mate. Mating usually takes place around the nest site, e.g., in Epicharis (Hiller and Wittmann, 1994; Gaglianone, 2005) and in Nomia (Mayer and Miliczky, 1998), or on the flowers where females specialize in pollen collection, e.g., in Ancyloscelis (Alves-dos-Santos, 1999) and Cephalurgus (Gaglianone, 2000). Males perform patrolling behavior, flying fast and checking the places where females can be found (inside the flowers or emerging from the nest), and they sometimes visit flowers to consume nectar. Males of some species also define and guard territories, such as Protomeliturga (Andrenidae: Medeiros and Schlindwein, 2003) and carpenter bees of the genus Xylocopa (Apidae) (Gerling and Hermann, 1978), which mate with females that nest and fly within their territories. In the middle or late afternoon they stop their patrolling and move to a sleeping roost.

Males of solitary bees usually do not spend the night inside the nests the females are constructing; instead, they must find a place to rest during the night. This place can be small branches of plants, cavities and flowers (Kaiser, 1995; Alcock, 1998; Alvesdos-Santos, 1999; Oliveira and de Castro, 2002). Males of Ptiloglossa goffergei Moure, for example, have been observed resting during the night in bamboo trap-nests in the "Restinga" (Gaglianone MC, personal observation). Flowers of Sida (Malvaceae) are used by males of Perditomorpha brunerii (Ashmead), which go into the flower when it is closing, remain motionless around the staminal tube on the base of the corolla until the next day, and they leave the flower before it falls (Gaglianone, 2000). Males of Hexantheda missionica Ogloblin (Colletidae) use flowers of Calibrachoa elegans (Solanaceae) to spend the night (Stehmann and Semir, 2001), while males of Melitoma segmentaria (Fabricius) (Apidae) are commonly found in flowers of Ipomoea; when the flower is wilted the next day the male cuts through the petal to leave the enclosure (Alves-dosSantos I, personal observation).

Sometimes males group with other individuals of the same species and return to the same place each evening throughout their life, exhibiting site fidelity to a particular plant (Rau and Rau, 1916; Evans and Linsley, 1960). In the sleeping place, they usually hang by their mandibles or accommodate themselves in the bottom of the flowers, and they stay in this position until the next day. In many species, they scrape their legs on the body (perhaps spreading chemical cues). In the morning they start the activities again and proceed with their daily cycle.

Alcock (1998) reported aggregations of Idiomelissodes duplocincta (Cockerell) (Eucerini), with hundreds of males roosting on stems of shrubs in Arizona. Usually the sleeping clusters are composed of a single species, but Rau and Rau (1916) and Evans and Linsley (1960) found that the aggregations can sometimes be composed of multiple species. Evans and Linsley (1960) classified aggregations into dense (ball-like) or loose (males sharing the same site but not maintaining physical contact), depending on the fidelity and return of individuals to the sleeping roost each evening and the composition of the aggregation (loose aggregations 
may be of diverse species). Alcock (1998) and Wcislo (2003) reported that site fidelity can be maintained across and between seasons, meaning that different generations intermingle. Sleeping sites of males of oligolectic species (i.e., those species in which the females collect pollen from one or a few plant species) tend to remain close to the area where their preferred plant occurs, and consequently where males patrol for females during the day (Alves-dosSantos, 1999; Gaglianone, 2000).

In the Neotropical region, females of three tribes of bees collect floral oils to surface the nest and to add to larval food; they are: Centridini, Tapinotaspidini, and Tetrapediini. These bees are termed oil-collecting bees, or just oil bees. While several studies have been undertaken on the nesting biology of Brazilian oil bees, few of them have reported on male biology (Alves-dos-Santos et al., 2002; Cunha and Blochtein, 2003; Gaglianone, 2001, 2005; Rozen et al., 2006). We report here on the sleeping location of males of some oil-collecting bee species of these three tribes.

\section{MATERIAL AND METHODS}

During field studies in south and southeastern Brazil over the last 10 years, dormitories of male bees were found and observed. The males were counted and their arrangement in the dormitory noted. Simple experiments were performed to test the fidelity to the sleeping site by marking the dorsum of the mesosoma with colored paint (in Tetrapedia); we also disturbed the individuals and observed their reactions. Representative specimens were collected for identification and were deposited in the Entomological Collection (Cepann) of the Bee Laboratory of the University of São Paulo and in the Entomological Museum at the Universidade Estadual do Norte Fluminense Darcy Ribeiro (UENF). The bees were identified with taxonomic keys and by comparison with reference material. The study area included Atlantic Rainforest in southern Brazil (Rio Grande do Sul and Santa Catarina), and restinga (Rio de Janeiro) and "cerrado" vegetations (São Paulo) in southeastern Brazil.

\section{RESULTS AND DISCUSSION}

\section{Centridini: Centris}

Centris lutea Friese is relatively widespread in Brazil, occurring from São Paulo to Rio Grande do Norte (Silveira et al., 2002). They are large bees, approximately $20 \mathrm{~mm}$ in length, with typical dense yellow pilosity on the mesosoma. We found two males of $C$. lutea in the late afternoon (about 17:30) on May 9 (autumn season) inside the dry fruit of Kielmeyera coriacea Mart. and Zucc Clusiaceae (Figure 1) in the Parque Estadual de Itirapina, São Paulo State ( $\left.22^{\circ} 11^{\prime} \mathrm{S} / 47^{\circ} 56^{\prime} \mathrm{W}\right)$. This is a Brazilian savanna ("Cerrado") area. The two males were in one of the carpels of the fruit capsule, which was already open. They were grasping the substrate with the mandibles, with the body held vertically over the substrate (Figure 1b,d). They were not visible without manipulation of the fruit. When disturbed the place, they flew away, first flying in circles around the tree and then flying further away. A few minutes later they returned to the same place, first circling the tree and approaching slowly to the same fruit in which they previously rested. After a few minutes they settled again into the interior of the fruit. 

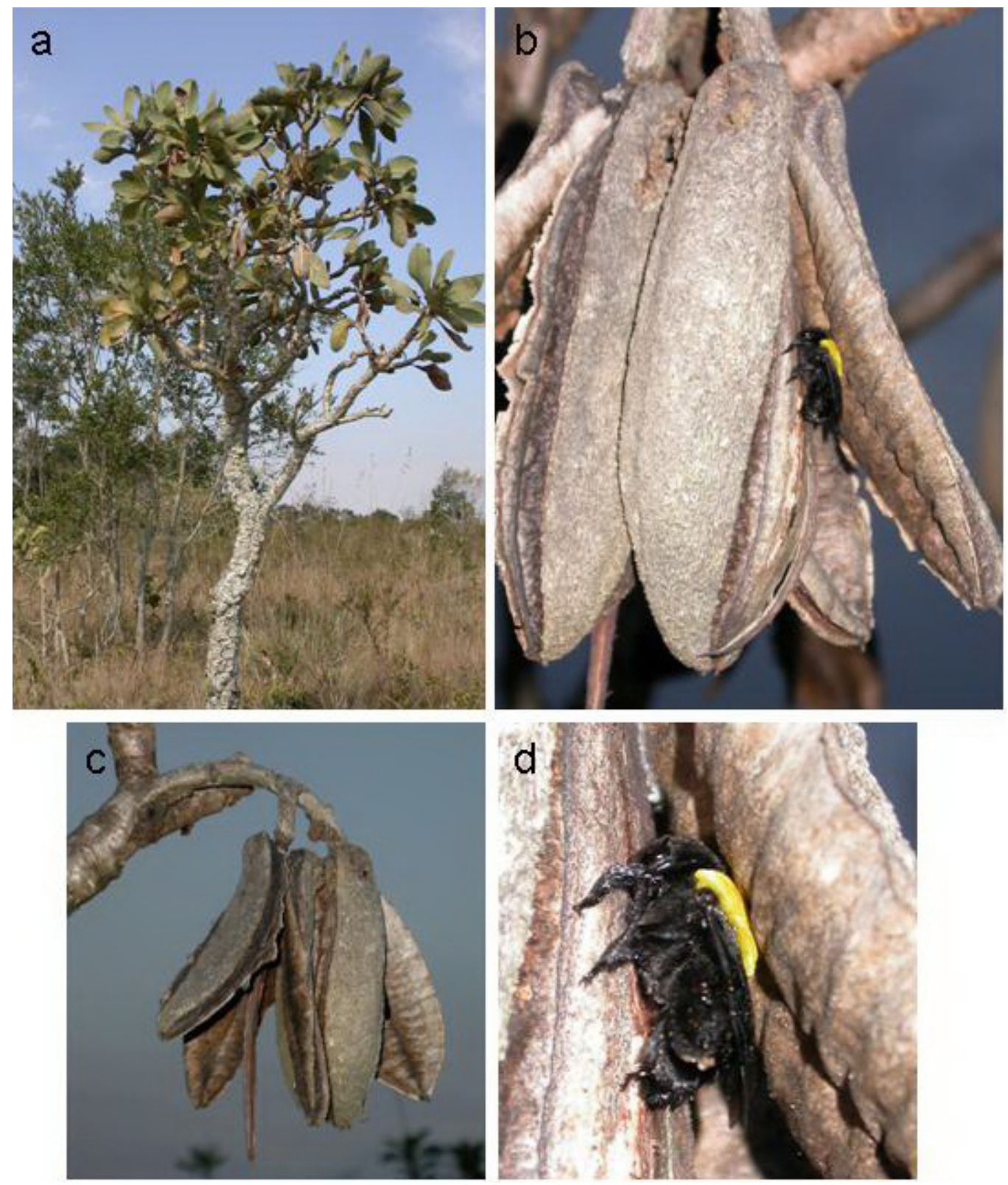

Figure 1. Sleeping place of Centris lutea: a. Kielmeyera coriacea, very common in the Cerrado vegetation; b. male of $C$. lutea found inside the fruit; c. some open dry fruits of $K$. coriacea, which remain in the tree for a long period; d. male of $C$. lutea grasping the capsule with its mandibles.

The plant they used as a sleeping site, Kielmeyera coriacea, is very common in the "Cerrado" of Itirapina, it occurs in the different physiognomies of savanna-type vegeta- 
tion ("cerrado" sensum stricto and open "cerrado"), being seldom found in the "cerradão" (characterized by tall trees and bushes; Durigan et al., 2004). The fruit is dry, dehiscent, oblong, light brown, and about $15 \mathrm{~cm}$ long (Figure 1c). The fruiting period is very long, and the fruit can take 12 months to reach maturation, when it opens and the seeds are dispersed by the wind (Rodrigues-Munhos, 2007). Even after it opens, the fruit remains in the tree for a long period, which makes them a good shelter for males of $C$. lutea and as a place to use as a dormitory. We believe that many plants from the Brazilian savanna that have dry fruits like this Clusiaceae are candidates for use as dormitories by solitary bees, and by other insects. This possibility should be checked in the future.

Centris leprieuri (Spinola) occurs in coastal areas, such as beach dunes in the States of Maranhão and Rio Grande do Norte (Gottsberger et al., 1988). In Rio de Janeiro State, these bees have been observed in semidecidous forest near the coast (São Francisco do Itabapoana, Mata do Carvão, ca. $5 \mathrm{~km}$ from the coast), restinga and beach vegetation (Gaglianone, 2006). A male aggregation of this species was observed on January 9 in Macaé (RJ) in the prostrate strand vegetation formed mainly by Ipomoea pes-caprae (L.) R.Br. (Convolvulaceae) and Canavalia rosea (Sw.) DC (Leguminosae). These plant species are used by males and females as nectar sources in that area. Approximately 15 males were found in the aggregation in the late afternoon, when the males were found together on a stem of $C$. rosea. When disturbed, the males flew around and returned to the previous position again some minutes later. Gottsberger et al. (1988) described the sleeping male aggregation of C. leprieuri in beach dunes in Maranhão, where this bee is resident and excavates nests in sand. Floral oils are not available in beach vegetation, but in ecosystems nearby; in Macaé (RJ), females of C. leprieuri were found in flowers of Byrsonima sericea located in the restinga formation, and in São Francisco do Itabapoana (RJ) females collected oil in flowers of Heteropterys chrysophylla (Lam.) Kunth in the semidecidous forest. Sleeping sites of males on nectar plants and around the nesting site seems to be a very common strategy, possibly to optimize foraging and searching for females during the following morning.

\section{Tapinotaspidini: Lanthanomelissa, Paratetrapedia, and Monoeca}

We have records of the sleeping place of the small bees of the genus Lanthanomelissa, which has a subtropical distribution, occurring in Argentina and southern Brazil. The females are narrowly specialized to flowers of Sysirinchium (Iridaceae), from which they collect oil and pollen (Truylio et al., 2002; Rozen et al., 2006). Species of Lanthanomelissa have a restricted season of activity, overlapping with the host plant bloom period. In southern Brazil, they are active during the springtime, from October through November. A cluster of five males of Lanthanomelissa betinae (Urban, 1995) was observed inside a flower of Petunia integrifolia in Terra de Areia, Rio Grande do Sul $\left(29^{\circ} 35^{\prime} \mathrm{S} / 50^{\circ} 04^{\prime} \mathrm{W}\right)$. The bees were set in the bottom of the corolla arranged in a series one behind the other, forming a rough circle. This species was also observed in other flowers, including Asteraceae and Oxalis (Oxalidaceae), although in these cases the bees were alone, not in clusters, and just resting over the flower stamens, or with the head inside the flower (tubular flower) (Figure 2a-c). Similar resting sites were observed in Curitiba in different species of Asteraceae (Rozen et al., 2006). Schlindwein (1995) reported sleeping males of Chalepogenus goeldianus (Friese) (cited as Lanthanomelissa goeldiana) in flowers of Calibrachoa ovalifolia (Miers) Stehmann and Semir (cited as Petunia ovalifolia) in the pampas. In spite of the impression 
that these bees seem to prefer flowers in which to sleep rather then stems, males of L. betinae were observed on the top leaves of some herbaceous plants (Rozen et al., 2006).
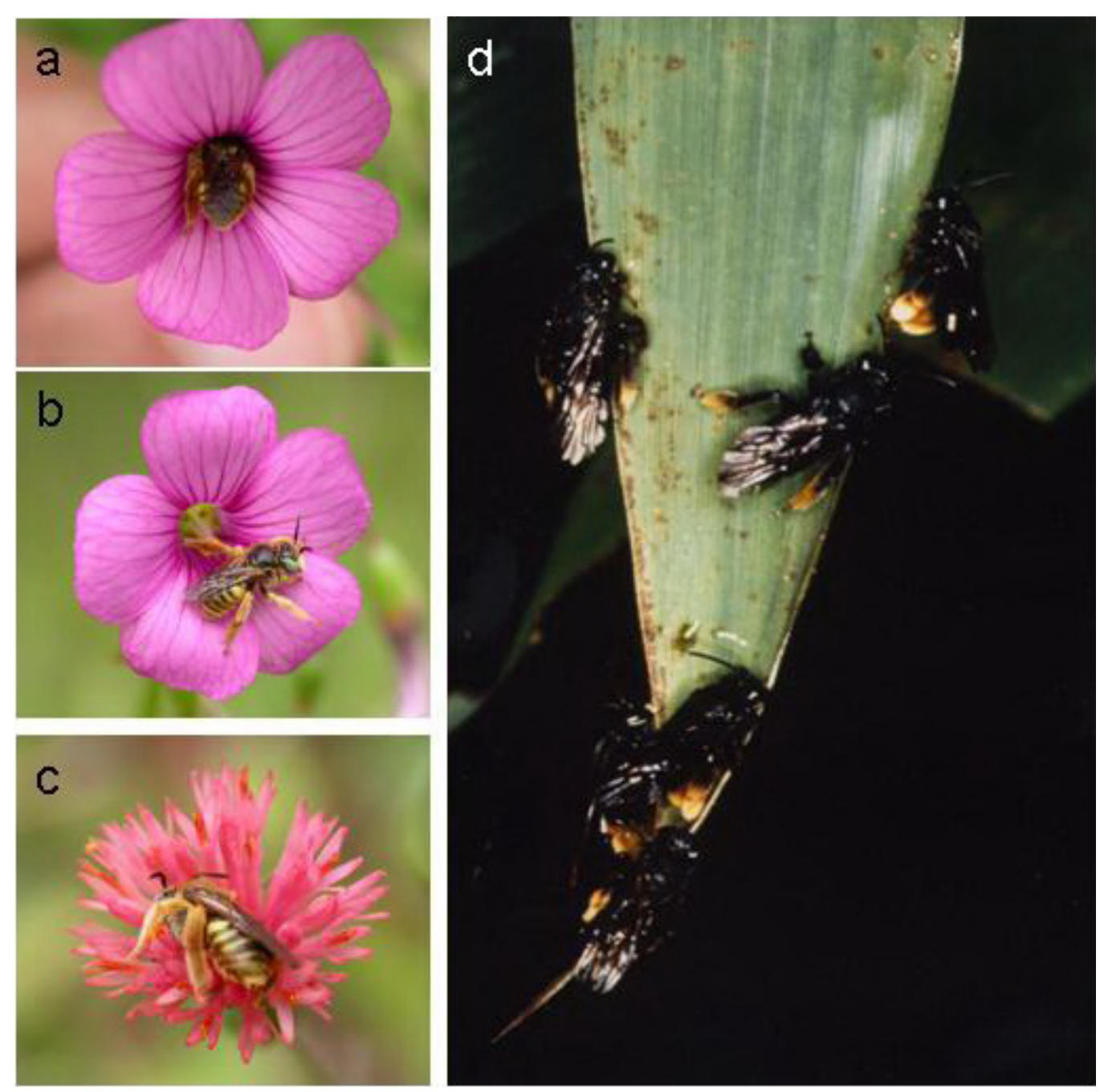

Figure 2. Tapinotaspidine bee sleeping places: a-c. Males of Lanthanomelissa betinae on flowers (Oxalidaceae and Asteraceae); d. males of Paratetrapedia sp grasping the foliage, where they spend the night.

A sleeping aggregation of Paratetrapedia sp was found in the late afternoon on a path inside a rainforest fragment. The area is located in the Atlantic Forest domain and belongs to the Serra Geral reserve, in the district of Maquiné, Rio Grande do Sul, southern Brazil $\left(29^{\circ} 35^{\prime} \mathrm{S} / 50^{\circ} 10^{\prime} \mathrm{W}\right)$. Eight males were resting on the foliage of a ruderal plant, biting the edge of the leaf with their mandibles, but with the body supported on the leaf 
(Figure 2d). Brief perturbation did not seem to annoy the males, although they did shift position a little and were soon grasping another part of the leaf.

Monoeca brasiliensis Lepeletier de Saint Fargeau and Audinet-Serville is a seasonal species observed on flowers at the end of the wet season (March-April) in Brazilian savanna ("cerrado") areas in São Paulo State. A sleeping aggregation of this species was found in Luiz Antonio, SP (Estação Ecológica de Jataí) on March 5th. The males (20-25) were located after $4 \mathrm{pm}$ hanging on dried stems of an unidentified species at approximately $1.5 \mathrm{~m}$ high in "cerrado" vegetation. They formed a dense aggregation and mild perturbation did not result in dispersion of the males. In the same area, males were also observed searching for females on Banisteriopsis adenopoda (A. Juss.) B. Gates flowers, where copulation probably occurred. Females have been seen collecting floral oils on flowers of Banisteriopsis and Tetrapterys in the same area.

\section{Tetrapediini: Tetrapedia}

A cluster of Tetrapedia diversipes was detected on the campus of the University of São Paulo, in São Paulo, close to the female nesting place, in trap-nest experiments (Alves-dos-Santos et al., 2002). The males roost in the late afternoon together on the same stems of a brittlebush during a few months (October through December). As reported for other solitary bees (like Eucerini) they tend to occupy the tip of the stem. Some marked males returned to the same stem over several days, exhibiting site fidelity, although other dry stems were available in similar situation. We suspect that odor cues are applied by the males that help them to locate the favored stems. They cling to the branch by their mandibles and leave their body hanging or extend it in a nearly perpendicular position relative to the stem (Figure 3). The males remain immobile throughout the night. It was observed that the males rub their hind-legs against each other for a while (Figure $3 b$ ) and against the body. The inner surface of the metabasitarsus of male Tetrapedia is modified into a broad and smooth structure (Figure 3d-f), perhaps with glandular pores (Alves-dos-Santos I and Patrício EFLRA, unpublished results). The sixth and seventh terga are also modified in males, holding a kind of brush made of dense plumose setae mixed with some simple and long setae (Figure 3c). The function of this brush remains unknown, but we suppose that it may be used to rub the hind legs and activate a glandular secretion. This movement may correspond to the observation described above in the sleeping location or it is used in another moment that we did not witness.

Studies on the sleep of insects started in the beginning of the Twentieth century from a physiological (Fiebrig, 1912 apud Rau and Rau, 1916) and an ecological (Rau and Rau, 1916) approach. Despite considerable interest in the subject, we still have little knowledge about nocturnal behavior, particularly in the order Hymenoptera where diurnal activities are so intensely scrutinized. This is more critical when it deals on the neglected gender, the males (Koeniger, 2005). Besides some bees in which the males return to the original nest, such as Xylocopa (Gerling and Hermann, 1978), we suppose that most male bees spend the night outside the nest. The examples presented here, as well as those from the literature, point to a variety of possible places, such as in plant stems, leaves, flowers, dry fruits, and bird nest (Azevedo and Faria Jr., 2007), furthermore we note that many species aggregate in few individuals (as the two C. lutea) or in large groups with more than 200 in the same spot like I. duplocincta (Alcock, 1998). The 

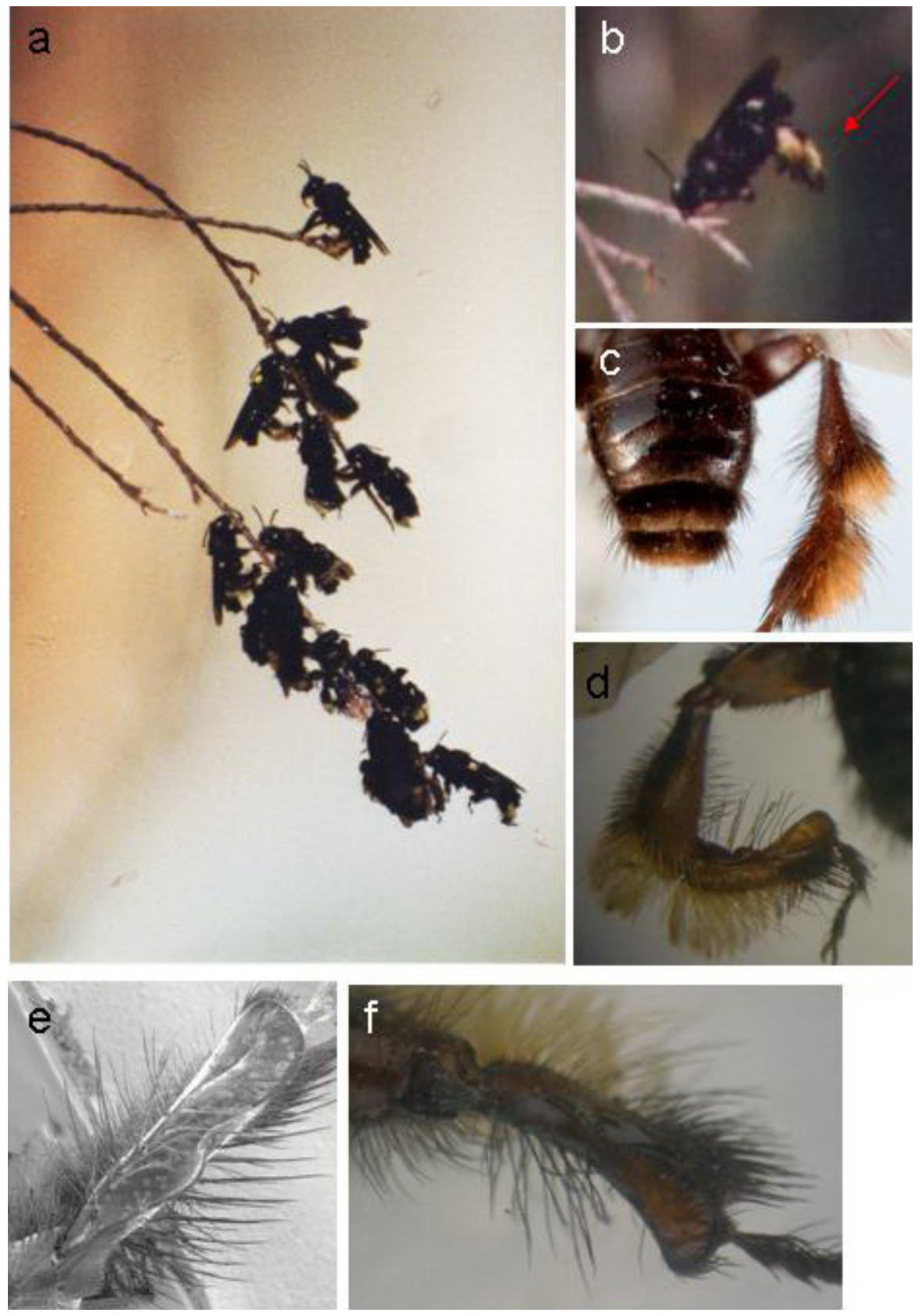

Figure 3. Males of Tetrapedia diversipes at sleep: a. a cluster of 15 males on a dry stem used during a few months; b. one of these males holding on by the mandibles and rubbing its hindlegs; $\mathbf{c}$. hind leg (dorsal) and metasoma of the male showing the dense brush on the sixth and seventh terga; d-f. ventral view of the hindleg showing the broad and smooth inner surface of the metabasitarsus, with possible glandular pores (e). 
reason why they form clusters remains unclear, but it is hypothesized to be a defensive strategy and related to chemical attraction. The males that sleep inside the flowers probably play a role in the reproductive system of the plants. This can be beneficial, i.e., helping the pollen transference, or potentially harmful. According to Dafni et al. (1981) the pollination of Serapias vomeracea (Orchidaceae) is performed by the bees that sleep inside the flowers, which is probably simulating holes in the ground. On the other side, males of $H$. missionica damage the flower by cutting the stamens and the style while they are preparing the shelter to accommodate themselves inside the corolla of Calibrachoa elegans (Solanaceae) (Stehmann and Semir, 2001). The potential costs and benefits of male roosting from a plant's perspective have not been rigorously explored and future investigators should explore these implications.

\section{ACKNOWLEDGMENTS}

We dedicate this paper to our friend and esteemed colleague Prof. Dr. Warwick E. Kerr, who has worked throughout his life to study bees in many aspects. We are grateful to the directors of the State Reserves of the Instituto Florestal, where we observed some of the bees. The financial support of FAPESP (\#04/00274-4) and FAPERJ (\#E-26/171.622/02) has been critical for our studies on oil-collecting bees, while the participation of M.S. Engel was supported by a Guggenheim Fellowship from the John Simon Guggenheim Memorial Foundation and by the U.S. National Science Foundation (\#EF-0341724).

\section{REFERENCES}

Alcock J (1998). Sleeping aggregations of the bee Idiomelissodes duplocincta (Cockerell) (Hymenoptera: Anthophorini) and their possible function. J. Kans. Ent. Soc. 71: 74-84.

Alves-dos-Santos I (1999). Aspectos morfológicos e comportamentais dos machos de Ancyloscelis Latreille (Hymenoptera, Apoidea). Rev. Bras. Zool. 16 (Suppl 2): 37-43.

Alves-dos-Santos I, Melo GAR and Rozen JG (2002). Biology and immature stages of the bee tribe Tetrapediini (Hymenoptera: Apidae). Am. Mus. Novitates 3377: 1-45.

Azevedo AA and Faria LRR Jr (2007). Nests of Phacellodomus rufifrons (Wied, 1821) (Aves: Furnariidae) as sleeping shelter for a solitary bee species (Apidae: Centridini) in southeastern Brazil. Lundiana 8: 53-55.

Cunha R and Blochtein B (2003). Bionomia de Monoeca xanthopyga Harter-Marques, Cunha and Moure (Hymenoptera, Apidae, Tapinotaspidini) no Planalto das Araucárias, Rio Grande do Sul, Brasil. Rev. Bras. Zool. 20: 107-113.

Dafni A, Ivri Y and Brantjes NBM (1981). Pollination of Serapias vomeracea Briq. (Orchidaceae) by imitation of holes for sleeping solitary male bees (Hymenoptera). Acta Bot. Neerl. 10: 69-73.

Durigan G, Baitello JB, Franco GADC and Siqueira MF (2004). Plantas do Cerrado Paulista: Imagens de uma Paisagem Ameaçada. Páginas \& Letras Editora e Gráfica, São Paulo.

Evans HE and Linsley EG (1960). Notes on a sleeping aggregation of solitary bees and wasps. Bull. South Calif. Acad. Sci. 59: 30-37.

Gaglianone MC (2000). Behavior on flowers, structures associated to pollen transport and nesting biology of Perditomorpha brunerii and Cephalurgus anomalus (Hymenoptera: Colletidae, Andrenidae). Rev. Biol. Trop. 48: 89-99.

Gaglianone MC (2001). Nidificação e forrageamento de Centris (Ptilotopus) scopipes Friese (Hymenoptera, Apidae). Rev. Bras. Zool. 18 (Suppl 1): 107-117.

Gaglianone MC (2005). Nesting biology, seasonality, and flower hosts of Epicharis nigrita (Friese, 1900) (Hymenoptera: Apidae: Centridini), with a comparative analysis for the genus. Stud. Neotrop. Fauna Env. 40: 191-200.

Gaglianone MC (2006). Centridini em Remanescentes de Mata Atlântica: Diversidade e Interações com Flores. In: Anais do VII Encontro sobre Abelhas (Santana WC, Lobo CH and Hartfelder KH, eds.). Ribeirão Preto, 335-340.

Gerling D and Hermann HR (1978). Biology and mating behavior of Xylocopa virginica L. (Hymenoptera, Anthophoridae). Behav. Ecol. Sociobiol. 3: 99-111. 
Gottsberger G, Camargo JMF and Silberbauer-Gottsberger I (1988). A bee-pollinated tropical community: The beach dune vegetation of Illha de São Luís, Maranhão, Brazil. Bot. Jahrb. Syst. 109: 469-500.

Hiller B and Wittmann D (1994). Seasonality, nesting biology and mating behavior of the oil-collecting bee Epicharis dejeanii (Anthophoridae, Centridini). Biociências 2: 107-124.

Kaiser W (1995). Rest at night in some solitary bees: a comparison with the sleep-like state of honey bees. Apidologie 26: $213-230$

Koeniger G (2005). The neglected gender - males in bees. Apidologie 36: 143-144.

Mayer DF and Miliczky ER (1998). Emergence, male behavior, and mating in the alkali bee, Nomia melanderi Cockerell (Hymenoptera: Halictidae). J. Kans. Entomol. Soc. 71: 61-68.

Medeiros PCR and Schlindwein C (2003). Territórios de machos, acasalamento, distribuição e relação com plantas em Protomeliturga turnerae (Ducke, 1907) (Hymenoptera, Andrenidae). Rev. Bras. Entomol. 47: 589-596.

Oliveira FF and de Castro MS (2002). Nota sobre o comportamento de agregação dos machos de Oxaea austera Gerstaecker (Hymenoptera, Apoidea, Oxaeinae) na caatinga do Estado da Bahia, Brasil. Rev. Bras. Zool. 19: 301-303.

Rau P and Rau N (1916). The sleep of insects; an ecological study. Ann. Entomol. Soc. Am. 9: 227-274.

Rodrigues-Munhos CB (2007). Kielmeyera coriacea Mart. ex Saddi. Available at [http://www.vivabrazil.com/vivabrazil/ kielmeyera_coriacea_mart_ex_saddi.htm]. Accessed May 10, 2007.

Rozen JG, Melo GAR, Aguiar AJC and Alves-dos-Santos I (2006). Nesting biologies and immature stages of the tapinotaspidine bee genera Monoeca and Lanthanomelissa and of their osirine cleptoparasites Protosiris and Parepeolus (Hymenoptera: Apidae: Apinae). Am. Mus. Novitates 3501: 1-66.

Schlindwein C (1995). Wildbienen und ihre Trachtpflanzen in einer südbrasilianischen Buschlandschaft: Fallstudie Guaritas, Bestäubung bei Kakteen und Loasaceen. Verlag Ulrich E. Grauer, Stuttgart.

Silveira FA, Melo GAR and Almeida EAB (2002). Abelhas brasileiras. Sistemática e Identificação. Fundação Araucária, Belo Horizonte.

Stehmann JR and Semir J (2001). Reproductive biology and biomass floral allocation in Solanum gardneri Sendth. (Solanaceae): an andromonoecious species. Rev. Bras. Bot. 24: 43-49.

Truylio B, Harter-Marques B and Engels W (2002). Biologia floral e polinização de Sisyrinchium micranthum Cavanillis 1788 (Iridaceae) na região do Planalto das Araucárias do Rio Grande do Sul, Brasil. Biociências 10: 11-24.

Urban D (1995). Especies novas de Lanthanomelissa Holmberg e de Lanthanella Michener \& Moure (Hymenoptera, Anthophoridae, Exomalopsinae). Rev. Bras. Zool. 12: 767-777.

Wcislo WT (2003). A male sleeping roost of a sweat bee, Augochlorella neglectula (Ckll.) (Hymenoptera: Halictidae), in Panamá. J. Kans. Entomol. Soc. 76: 55-59. 